FESIDE

Fundación Emilio Soldevilla de la Economía de la Empresa journal homepage: http://www.ehu.eus/cuadernosdegestion/revista/es/

ISSN: 1131-6837 / e-ISSN: 1988-2157

\title{
Trends and challenges in operations strategy research: Findings from a systematic literature review
}

\section{Tendencias y retos de investigación en estrategia de operaciones: hallazgos de una revisión sistemática de la literatura}

Jorge A. Vivares ${ }^{\star}$, Lucía Avella $^{\mathrm{a}}$, William Sarache ${ }^{\mathrm{b}}$

a Departamento de Administración de Empresas, Universidad de Oviedo. Avda. del Cristo s/n, 33006. Oviedo, España - lavella@uniovi.es - https://orcid.org/0000-00032598-7318

${ }^{b}$ Universidad Nacional de Colombia, Sede Manizales, Facultad de Ingeniería y Arquitectura, Departamento de Ingeniería Industrial. Cra. 27 \# 64-60, Campus Palogrande, 170004. Manizales, Colombia - wasarachec@unal.edu.co - https://orcid.org/0000-0003-3543-4151

* Corresponding author: Departamento de Ingeniería Industrial, Universidad Nacional Abierta y a Distancia. Diagonal 25F - Cra 23, 661001. Dosquebradas, Colombia-jorge.vivares@unad.edu.co-https://orcid.org/0000-0002-4818-5249

\section{A R T I C L E I N F O}

Received 28 June 2021,

Accepted 05 January 2022

Available online 4 March 2022

DOI: $10.5295 /$ cdg.211543ja

JEL: L21, M11

\section{A B S T R A C T}

Operations strategy is a mature field and requires novel insights for further research and practitioners in companies. To fill this gap, 280 articles were analyzed, by way of a systematic literature review, considering two approaches: topic perspectives (content, process, and competitive priorities), and research paradigms (analysis perspective, general methodology, research design, research typology, and alternative paradigms). Eight challenges were identified and discussed to make novel contributions to cutting-edge knowledge. Among other things, it was found that people's perceptions of object reality prevail as the dominant paradigm, regarding the source and type of information used. In this sense, the literature suggests additional investigation through the direct observation of object reality and experimental studies, in which the action research approach could play an important role as an alternative paradigm. Additionally, considering Industry 4.0 advances, new research opportunities have emerged which permit artificial reconstruction of object reality to support decision-making. The main contribution of this study is to discuss eight challenges by which to improve research relevance and make both academic and practical contributions. Moreover, several useful data for researchers are provided, including statistics regarding response rates in survey research (dominant paradigm). Finally, these findings can be used to perform further research with additional functional strategies in the companies.

Keywords: Operations Strategy, Manufacturing Strategy, Research Paradigms, Systematic Literature Review, Action Research. 


\section{R E S U M E N}

La estrategia de operaciones es un campo de estudio maduro, pero requiere perspectivas novedosas para la investigación futura y para los profesionales en las empresas. Para llenar este vacío, se analizaron 280 artículos mediante una revisión sistemática de la literatura, bajo dos enfoques: tópicos (contenido, proceso, prioridades competitivas) y paradigmas de investigación (perspectivas, metodología, diseños, tipologías y paradigmas alternativos de la investigación). Se identificaron y discutieron ocho retos para hacer contribuciones novedosas en las fronteras del conocimiento. Entre otras cuestiones, respecto a la fuente y tipo de información utilizada, se encontró que el paradigma dominante de investigación se relaciona con las percepciones de la gente sobre la realidad objeto de estudio. En este sentido, la literatura sugiere incrementar la investigación a través de la observación directa de la realidad y los estudios experimentales, en lo cual la investigación acción puede jugar un rol importante como paradigma alternativo. Adicionalmente, considerando los avances de la Industria 4.0, han emergido nuevas oportunidades de investigación que permiten la reconstrucción artificial de la realidad para apoyar la toma de decisiones. La principal contribución de este estudio es la discusión de ocho retos para mejorar la relevancia de la investigación y hacer contribuciones tanto académicas como prácticas. Además, se proporcionan varios datos útiles para los investigadores como la tasa de respuesta en la investigación con encuestas (paradigma dominante), entre otros. Finalmente, los hallazgos pueden ser utilizados para investigar otras estrategias funcionales para las empresas.

Palabras clave: Estrategia de Operaciones, Estrategia de Manufactura, Paradigmas de Investigación, Revisión Sistemática de la Literatura, Investigación Acción. 


\section{INTRODUCTION}

Corporate and competitive strategies are a starting point for functional strategy development in areas such as finances, marketing, operations, and purchasing, among others. Operations Strategy (OS) is a functional strategy "....concerned with how the competitive environment is changing and what the operation has to do in order to meet current and future challenges (Slack and Lewis 2011, p. 7)". OS is a long-term plan, in which actions to be performed are established, so as to achieve the competitive advantages derived from a manufacturing/operations system (Arana-Solares et al. 2019). OS has drawn the attention of investigators and practitioners in countries the world over, which is reflected in the high number of publications present in specialized journals and books. Owing to this growth, OS study constitutes a body of knowledge which merits permanent monitoring.

As shown in Table 1, four OS literature reviews have been published in the past. These addressed themes related to OS, content/process, and certain methodological issues. The analysis of the present study revealed that two relevant topics require indepth OS review because they were not encompassed in previous studies: a) trade-off and sand cone themes, and b) research paradigms. Furthermore, it is necessary to analyze research published in the past several years because Chatha and Butt (2015) and Chatha et al.'s (2015) studies included articles published in and prior to 2010 exclusively, and only considered "manufacturing strategy" key in their main strategy search (herein, however, the evolution from manufacturing strategy to operations strategy is discussed, and both terms were used in the strategy search).

Table 1

Previous OS literature review studies

\begin{tabular}{|c|c|c|c|c|c|}
\hline \multirow[b]{2}{*}{ Analysis criteria } & \multicolumn{5}{|c|}{ Authors } \\
\hline & $\begin{array}{c}\text { Dangayach and } \\
\text { Deshmukh (2001) }\end{array}$ & Boyer et al. (2005) & Chatha and Butt (2015) & $\begin{array}{l}\text { Chatha et al. } \\
\qquad(2015)\end{array}$ & This study \\
\hline Source of the search & $\begin{array}{l}31 \text { journals and } \\
\text { international } \\
\text { conferences }\end{array}$ & $\begin{array}{l}\text { Focused on one } \\
\text { journal (POM) }\end{array}$ & $\begin{array}{l}\text { Business Source Premier. } \\
\text { References in four articles }\end{array}$ & $\begin{array}{l}\text { Business Source } \\
\text { Premier }\end{array}$ & $\begin{array}{l}\text { Scopus and Tree } \\
\text { of Science (ToS) }\end{array}$ \\
\hline "Manufacturing strategy" term & * & * & * & * & * \\
\hline “Operations strategy" term & * & * & & & * \\
\hline Number of articles analyzed & 260 & 31 & 506 & 512 & 280 \\
\hline Annual rate of articles analyzed & 8.1 & 2.4 & 11.2 & 11.4 & 16.5 \\
\hline Number of journals encompassed & $\begin{array}{l}21 \text { journals and } \\
10 \text { international } \\
\text { conferences }\end{array}$ & 1 & 34 & 34 & 105 \\
\hline
\end{tabular}

By topic

\begin{tabular}{lllll} 
Content & $*$ & $*$ & $*$ & $*$ \\
\hline Process & $*$ & $*$ & $*$ & $*$ \\
\hline Content and process & & $*$ & $*$ & $*$ \\
\hline Trade-off and sand cone models & & & & $*$
\end{tabular}

\begin{tabular}{|c|c|c|c|c|}
\hline By research paradigm & & & & * \\
\hline General methodological approach $^{(1)}$ & * & * & * & * \\
\hline Specific research design ${ }^{(2)}$ & & & * & * \\
\hline Specific method or technique & & & * & * \\
\hline By research typology $y^{(4)}$ & & & & * \\
\hline
\end{tabular}

Research alternatives paradigms ${ }^{(3)}$

Notes: (1) Qualitative, quantitative, or mixed. ${ }^{(2)}$ Not experimental, experimental. ${ }^{(3)}$ Based on Meredith et al. (1989) and Craighead and Meredith's (2008): natural/artificial and rational/existential dimensions. ${ }^{(4)}$ Two typologies: classical, and Phillips and Pugh's (2010) improved typology. ${ }^{\star}$ Indicates element presence.

Source: Author elaboration based on the cited references. 
The present article expounds upon the results of a systematic literature review, which attempts to close the above-mentioned gaps. The underpinning of the search strategy was based on queries made in the Scopus database, and the use of a tool called Tree of Science (ToS). A total of 280 articles were analyzed. As a main contribution, eight challenges were identified and discussed for further research, in order to make novel contributions to cutting-edge knowledge. For example, on analysis of research paradigms, as proposed by Meredith et al. (1989), it was found that the current dominant OS paradigm is "People's perceptions of object reality," as well as the "Logical positivist/empiricist" paradigm. Findings suggest increasing the presence of alternative research paradigms (but not the replacement of the current dominant paradigm), based on "direct observation of object reality", and "artificial reconstructions of reality".

The remainder of the article is structured as follows: in Section 2, a conceptualization of the OS field, as well as the corresponding paradigms, are presented to lay a theoretical foundation for the review. The investigation's methodology is explicated in Section 3. In Section 4, the main results identified are exhibited. Finally, discussion and conclusions are presented in sections 5 and 6 , respectively.

\section{BACKGROUND}

\subsection{From Manufacturing Strategy (MS) to Operations Strategy (OS)}

A number of authors recognize that MS emerged as a field of study following the seminal contributions of Wickham Skinner (1966, 1969). Subsequently, further relevant investigations, published by Skinner (1974), Hayes and Schmenner (1978), Wheelwright (1978), Schmenner (1982), Hayes and Wheelwright (1984), and Wheelwright (1984), among others, aided in the consolidation of the MS' theoretical foundations. Despite its status as a mature field, Kulkarni et al. (2019) assessed the paradox in the difference between academic and industry definitions, using text mining, and found some misalignment.

The term "manufacturing strategy" was originally used, due to its link with companies that produced goods. For Wheelwright “...a manufacturing strategy consists of a sequence of decisions that will enable a business unit to achieve its desired competitive advantage (Wheelwright 1984, p. 85)". However, as the service sector became stronger, this concept evolved, until it became "Operations Strategy". This concept entails an action field in the production of goods (tangible) and services (intangible), in all types of organizations (service and manufacturing companies, large and small, for- and not-for-profit organizations). According to Slack and Lewis (2011, p. 7) "Operations strategy is concerned less with individual processes and more with the total transformation process that is the whole business" and this implies similarities at a strategic level in different types of companies.

Two components should be addressed in OS study: content and process (Leong et al. 1990). OS content defines its performance objectives, as well as the form in which operations system strategic decision areas are to be adjusted (Drohomeretski et al. 2014). The two fundamental elements of OS content study are: competitive priorities and strategic decision areas. Competitive priorities refer to an operations system's performance objectives. In the literature, the most common competitive priorities are: cost, quality, flexibility, innovativeness (product), delivery, service, and environmental protection (da Silveira and Sousa 2010; Vivares et al. 2019). In order to manage competitive priorities, there are two dominant models to be analyzed: the trade-off (Skinner 1969, 1974), and the sand cone (Ferdows and De Meyer 1990).

The trade-off model proposes the need to emphasize one or few competitive priorities over others, as it is difficult to achieve strong performance in them all (Da Silveira and Slack 2001). The sand cone model proposes a capability accumulation strategy, which, from a continuous improvement approach, permits the achievement of strong performance in all competitive priorities, maintaining the quality $\rightarrow$ delivery $\rightarrow$ flexibility $\rightarrow$ cost sequence. Strategic decision areas represent subsystems which must be modified in order to develop distinctive capacities. These lead to compliance with performance objectives (competitive priorities). Strategic decision areas in the operations system include human resources, production planning and control, sourcing, process technology, facilities, and products (Miltenburg 2008).

In the OS process, the way in which OS is formulated and implemented is analyzed. A minimum of two components must be considered: 1) the pattern to direct decision-making, and 2) the model, methodology, or procedure for OS formulation and implementation. There are three main approaches in the literature for decision-making directions: top-down, bottom-up, and middle-out (Kim et al. 2014). In the OS formulation process, social, political, cultural, and learning values all come into play. Also, stakeholders' values, needs, and interests must be considered, which makes this a highly complex process. Its complexity indicates the need for the adoption of a model (Miltenburg 2008), methodology (Hill 2000), or procedure (Dangayach and Deshmukh 2001) adequate for OS design and development. Furthermore, some variables may be simultaneously associated with OS content and process, as was found by Vivares et al. (2019, p. 340) respect to Manufacturing's Strategic Role (MSR): “...is a missing link variable in the diverse OS frameworks studied... a renewed idea of OS is proposed in this study, which adds MSR as a fundamental element to the traditional content and process-based view".

\subsection{Research paradigms}

To begin, the concept of OS paradigms will be discussed, so as to define their use within the present document. The concept of paradigms is quite broad and has long merited discussion. Though the term was used in ancient Greek, Thomas Khun encouraged it in his celebrated essay entitled "The structure of scientific revolutions" and provided several definitions. Based on Corbetta's (2003) contribution, a paradigm may be understood as a theoretical perspective which has been accepted by the scientific community, is founded on previous knowledge from a given discipline, directs research through 
the specification of what to study, formulates hypotheses about a phenomenon, and selects the most suitable research techniques. Thus, paradigms are well-established beliefs about theories, methods, or approaches, which are phenomena or epistemological ways to study a given phenomenon and acquire knowledge.

There are several views from which to analyze paradigms in the OS field. For example, Voss (1995) reviewed the history of manufacturing strategy, and discussed theoretical paradigms which included key success factors, order winners, capabilities, process choices, contingent approaches, infrastructure approaches, and world class manufacturing, among others. From the epistemological point of view, Westbrook (1995) advocated that action research was a new paradigm for research in production and operations management, and that it constituted more than a single technique or method. In this study, special attention was paid to the framework for paradigm comprehension, as proposed by Meredith et al. (1989), in an article entitled "Alternative Research Paradigms in Operations".

Meredith et al. (1989) developed a framework for paradigms of research methods with two dimensions: the rational/existential and the natural/artificial. The first "relates to the epistemological structure of the research process itself (Meredith et al. 1989, p. 305)" and refers to three ways that a researcher may observe reality: direct observation of object reality, people's perceptions of object reality, and artificial reconstruction of object reality. The second dimension "...concerns the source and kind of information used in the research (p. 307)" and refers to four epistemological ways to analyze observations: from the axiomatic, logical positivist/empiricist, interpretative, and critical theory.

Despite its age, Meredith et al's (1989) framework remains relevant for the novel study of paradigms. The aforementioned authors used their framework to review the operations management state of the art, by employing a sample of articles published in a span of just two years (1977 and 1987), when Operations Strategy (OS) was just gaining traction as a new field of study. They observed that Operations Management (OM) investigation had concentrated on the "axiomatic" category of the rational/existential dimension, and the "artificial construction of reality" in the natural/artificial dimensions. Thereafter, Craighead and Meredith (2008) used the same framework to analyze a sample of OM articles from 1995 and 2003 (separately). They found little movement in people's perceptions of the object reality category in the natural/artificial dimensions, and to the "logical positivist/empiricist" category in the rational/existential dimensions. However, these studies addressed the OM field, and no studies were found to have used this framework for in-depth paradigm reviews in the OS field.

\section{METHODOLOGY}

Principles for the performance of a systematic literature review were applied (Bartels 2013; Granillo and González 2021; Orviz et al. 2021). Figure 1 shows the general methodology. First, the target of the review was delimited to answer two main questions: 1) What are the general features of the articles pub- lished on OS content and process (themes, methodologies, paradigms)? 2) What are the main areas in which further research may be conducted?

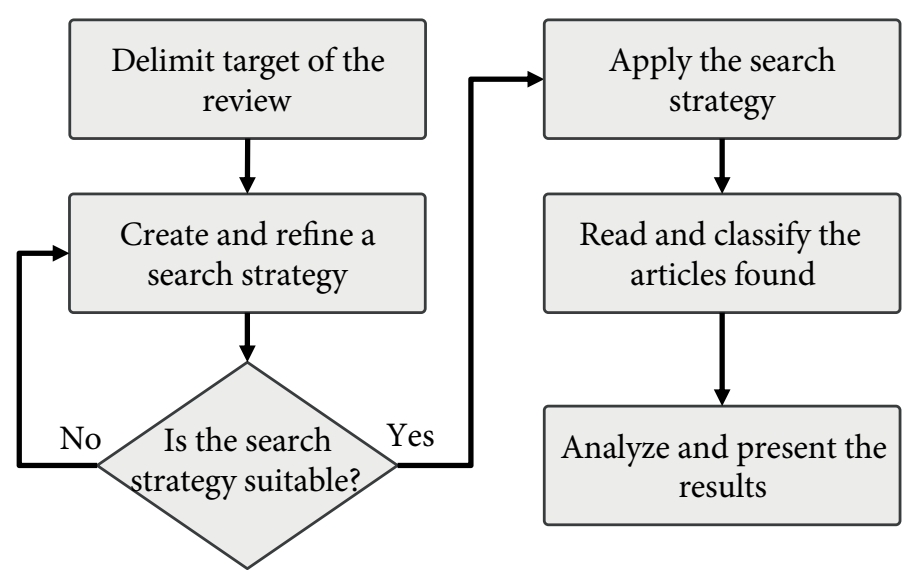

Figure 1

General methodology used in the systematic literature review Source: Author elaboration.

Second, a search strategy was created and refined in an iterative process, in accordance with two criteria (Bartels 2013): 1) relevance of the articles found, and 2) balance between quantity (sensitivity) and specificity. For this purpose, 22 relevant references were used. The refinement process was halted only while the search strategy identified these references. Third, the final search strategy was applied. The strategy had two main components: on the one hand, a search equation was created (Eq. 1) and applied in the Scopus database. This expression may be considered an equation which results in a $C$ set with $n$ references. These depend on source (database and search fields), the keywords, the time, as well as the document type $\left(C=\left\{r_{1}, r_{2}, \ldots, r_{n}\right\}=f\right.$ (source, keywords, time, document type)). The equation was applied using the TITLE-ABS-KEY field (title, abstract and keywords), beginning with the year 2001, and was limited by document type (LIMIT-TO (DOCTYPE)), article (ar), or review (re). Boolean operators (OR, AND) were used to join the keywords.

$f$ (source, keywords, time, document type $)=$ TITLEABS-KEY ("manufacturing strategy" OR "operations strategy") AND TITLE-ABS-KEY ("competitive priorities" OR "decision areas" OR "decision categories" OR levers OR taxonomy OR (tradeoff) OR "sand cone" OR (formulation process ${ }^{\star}$ ) OR (implementation process ${ }^{\star}$ ) OR (formalization process $^{\star}$ ) OR (formation process ${ }^{\star}$ ) OR (choice (c) $^{\star}$ process $^{\star}$ ) OR (choice ${ }^{\star}$ implementation) OR (strategic choice $^{\star}$ ) OR "stage model" ) AND TITLE-ABS-KEY (survey OR "case study ${ }^{\star}$ ” OR (literature review) OR framework OR interview* OR "conceptual model” OR "conceptual discussion" OR "action research" OR empirical) AND PUBYEAR $\geq 2001$ AND (LIMITTO (DOCTYPE, “ar”) OR LIMIT-TO (DOCTYPE, "re")). 
On the other hand, the Tree of Science (ToS) $)^{1}$ methodology, proposed by Robledo et al. (2014), was used in order to minimize bias. ToS is based on graph theory and detects relevant references, while minimizing the bias which results from searches performed in specific databases, and has been applied in recent research (Durán et al. 2021; Robledo et al. 2021). Subsequently, the search strategy was applied, and three criteria for inclusion/exclusion were established: a) the inclusion of articles related to OS management and strategic decisions, and exclusion of those related to technical issues in manufacturing or operations (e.g., physical transformation), b) the inclusion of articles, if the full text version was accessible to authors, c) the exclusion of duplicates. In order to classify the selected references, a protocol review was created, as suggested by Kitchenham (2004).

The articles were read and classified by typology (theoretical or evidentiary). Theoretical articles were classified into one of three categories: systematic reviews, conceptual articles or frameworks, and essays or reflections. Evidentiary articles were classified by topic (OS content and process, trade-off and sand cone models), and by research paradigm (see Table 2). In order to ensure reliability and a certain level of concordance among authors, an article classification audit was performed. Thus, doubts were discussed, a consensus was reached, and the review protocol was improved. Results from the analyses are presented below.

Table 2

Research paradigms for investigation performance (evidentiary articles)

\begin{tabular}{ll}
\hline \multicolumn{1}{c}{ Category } & \multicolumn{1}{c}{ Subcategories } \\
\hline Analysis perspective & Quantitative, qualitative, or mixed \\
\hline Research design & $\begin{array}{l}\text { Not experimental (data: cross-sectional, } \\
\text { longitudinal, panel, qualitative), or experimental }\end{array}$ \\
\hline $\begin{array}{l}\text { General } \\
\text { methodology }\end{array}$ & $\begin{array}{l}\text { Survey/interview (sample), case studies, } \\
\text { others (action research, artificial evidence), or } \\
\text { multiple }\end{array}$ \\
\hline Research typology 1 & $\begin{array}{l}\text { Historical, descriptive, correlational, } \\
\text { explanatory, exploratory, or qualitative }\end{array}$ \\
\hline Research typology 2 & $\begin{array}{l}\text { Exploratory, problem-solving, testing-out, or } \\
\text { theory-building. The first three were proposed } \\
\text { by Phillips and Pugh (2010), and theory } \\
\text { building was extracted from the literature } \\
\text { (Eisenhardt and Graebner 2007; Wacker 1998) } \\
\text { to complement the first proposal. }\end{array}$ \\
\hline $\begin{array}{l}\text { Research method } \\
\text { paradigms, } \\
\text { based on those } \\
\text { of Meredith } \\
\text { et al. (1989) and } \\
\begin{array}{l}\text { Craighead and } \\
\text { Meredith (2008) }\end{array}\end{array}$ & $\begin{array}{l}\text { 1) Natural/artificial dimension: direct } \\
\text { observation of object reality, people's } \\
\text { perceptions of object reality, or artificial } \\
\text { reconstruction of object reality. } \\
\text { 2) Rational/existential dimension: axiomatic, } \\
\text { logical positivist/empiricist, interpretative, or } \\
\text { mixed. }\end{array}$ \\
\hline Source: Author elation
\end{tabular}

Source: Author elaboration.

\footnotetext{
${ }^{1}$ https://tos.coreofscience.com/
}

\section{RESULTS}

A total of 319 unduplicated references were detected. Of these, 39 were discarded, as they did not comply with the inclusion criteria. This left 280 articles for the final analysis, $14.3 \%$ of which were theoretical (40), and the other $85.7 \%$ of which corresponded to 240 articles which incorporated evidence (whether empirical or artificial). Said 280 articles had been published in 105 different journals (between 2001 and 2017). Just eight of these journals had published $51 \%$ of said contributions. In a supplementary file, detailed information about the 280 articles analyzed is provided. The results revealed that an average of 16.5 OS articles are published per year $(\mathrm{DS}=1.234)$.

\subsection{Results of theoretical contributions}

Table 3 shows descriptive statistics about the theoretical contributions. Articles which conceptualized a topic and/or proposed frameworks were dominant. Two essays (or reflections) appeared: one in recognition of Bob Hayes' contributions (Fisher 2007), and another written by Skinner (2007), called "Manufacturing strategy: The story of its evolution".

Table 3

Theoretical articles

\begin{tabular}{lcccc}
\hline \multirow{2}{*}{ Categories } & \multicolumn{3}{c}{ Results } & \\
\cline { 2 - 4 } & Quantitative & Qualitative & & \\
\hline Systematic review & 9 & 2 & 11 & 27.5 \\
$\begin{array}{l}\text { Conceptualizations or } \\
\text { frameworks }\end{array}$ & & 27 & 27 & 67.5 \\
Essays or reflections & & 2 & 2 & 5.0 \\
\hline \multicolumn{1}{c}{ Total } & $\mathbf{9}$ & $\mathbf{3 1}$ & $\mathbf{4 0}$ & $\mathbf{1 0 0}$ \\
\hline \multicolumn{1}{c}{$\%$ Column } & 22.5 & 77.5 & 100 & \\
\hline
\end{tabular}

Source: Author elaboration.

\subsection{Evidentiary articles (empirical or artificial evidence)}

A total of 240 articles detected provided empirical or artificial evidence regarding their respective objects of study. Below, the results are presented, organized by topic addressed and research paradigm.

\section{A. Results By topic AdDRessed}

From a thematic point of view, OS investigation has focused on content $(74 \%)$, while just $6 \%$ has been oriented toward the study of process. The remaining $20 \%$ has simultaneously studied process and content variables. In Figure 2, the number of investigations addressing process, content, or both topics, is presented. For those studies focused on process, in addition to being the scarcest type, they were also the most intermittent, given that not a single contribution was registered in seven of the 17 years analyzed. 


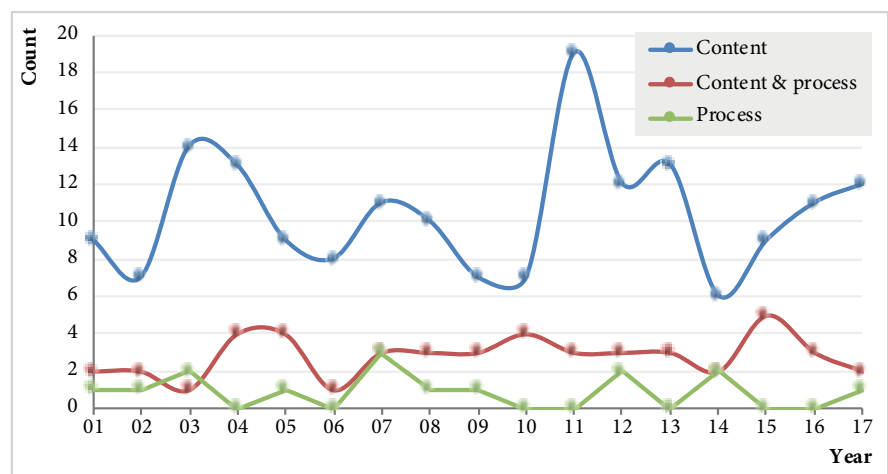

Figure 2

Longitudinal results by $\mathrm{OS}$ topic

Source: Author elaboration.

Based on 63 articles including process variables, it was noted that certain contributions, which studied models, methodologies, or procedures that supported decision making, were notable $(67 \%)$. However, it was established that the majority of said investigations addressed specific OS decisions, and did not consider matters regarding its general configuration, formulation, or implementation. Topics, such as pattern analysis in decision-making and diverse topics involved in the process, have received scant attention in the literature: top down (16\%), bottom up (16\%), and mixed (6\%).

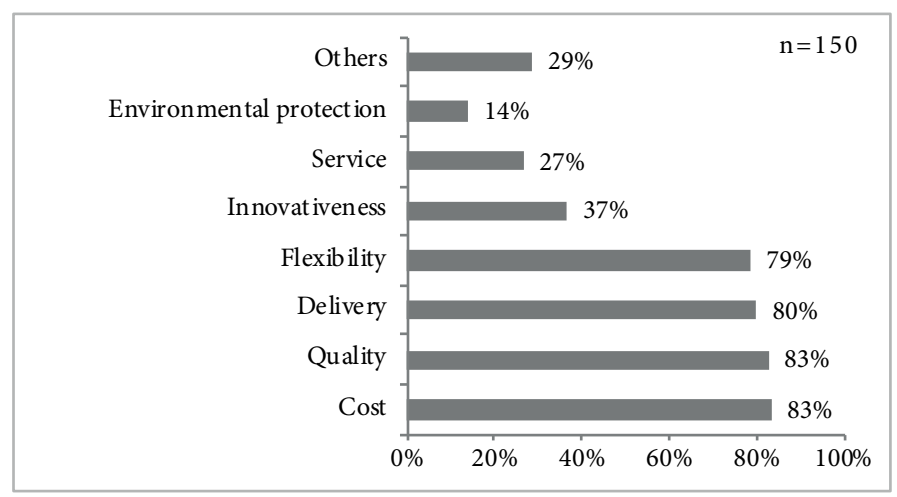

3a. Competitive priorities

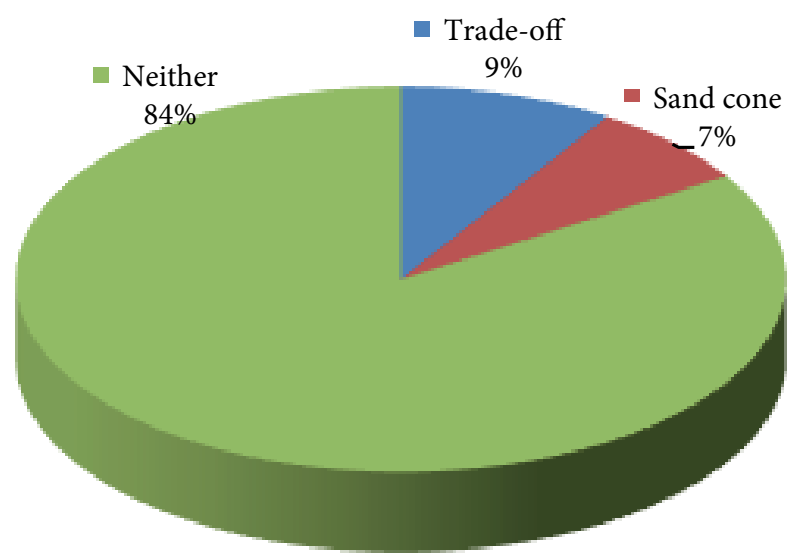

3b. Models tested

Figure 3

Competitive priorities and their analytical paradigms

Source: Author elaboration.
Contributions that have addressed OS content variables ( $n=225$ ) have concentrated principally on the study of competitive priorities (67\%), and in lesser proportions, on one or several strategic decision areas (52\%). In Figure 3 a summary of articles which address competitive priorities are presented. Note that cost, quality, flexibility, and delivery are the most recurrent (Figure 3a). Furthermore, it was found that $9 \%$ of the articles empirically tested the trade-off model, and $7 \%$ tested the sand cone model (Figure 3b).

\section{B. RESEARCH PARADIGM RESUltS}

The results presented in Table 4 indicate that the majority of investigations were based on surveys/interviews applied in companies, with employees or experts (55\%). In investigations that used the surveys applied in companies $(n=117)$, the average response rate was $33.7 \%$ (minimum: $5.6 \%$, maximum: $86.1 \%)$ and the quartile distribution is as follows: quartile 1 (17.9\%), quartile $2(26.4 \%)$, quartile $3(45.3 \%)$, and quartile 4 (86.1\%). This result may be useful for future studies based on survey research. Case studies represented $29.6 \%$ of the total, and other types of investigation (action research, and artificial evidence, among others), together with the use of multiple approaches, represented $7.5 \%$ and $7.9 \%$, respectively. From the perspective of analysis, studies with quantitative approaches represented $56.7 \%$ of the investigations, followed by qualitative approaches, which constituted $22.9 \%$. Finally, $20.4 \%$ of the investigations used mixed perspectives. Following the longitudinal evaluation of these variables, no patterns or tendencies were found.

In regard to research design, the majority of the studies were not experimental (98\%). In this category (see Table 5), investigations with transversal data were prevalent. There were few longitudinal contributions. Studies with panel data were not detected either. However, five experimental investigations were found, which, although marginal, indicate that investigation from this perspective is indeed possible. Said studies were completed in the early 2000s (Pullman et al. 2001; Stading et al. 2001; Lee et al. 2002; Li et al. 2006; AlDurgham and Barghash 2008).

Research typology showed that most of the studies gathered were either descriptive (25.9\%) or explanatory (38.3\%) (see Table 6). In fact, no study regarding OS history was found at all. From the perspective of Phillips and Pugh (2010), testing-out methods, those which attempted to test or refute theories, conformed the majority $(49.2 \%)$, while the least frequent were those of the theory-building type. 
Table 4

General methodology and analysis perspective

\begin{tabular}{|c|c|c|c|c|c|}
\hline \multirow{2}{*}{ Category } & \multicolumn{3}{|c|}{ Analysis perspective } & \multirow{2}{*}{ Total } & \multirow{2}{*}{ \% Row } \\
\hline & Quantitative & Qualitative & Mixed & & \\
\hline Survey/interview (sample) & 117 & 1 & 14 & 132 & 55.0 \\
\hline Sample of companies & 106 & & 12 & 118 & 49.2 \\
\hline Sample of employees & 4 & 1 & 2 & 7 & 2.9 \\
\hline Sample of experts & 7 & & & 7 & 2.9 \\
\hline Case studies & 8 & 46 & 17 & 71 & 29.6 \\
\hline Single case study & 3 & 13 & 11 & 27 & 11.3 \\
\hline Multiple case study (2-4) & 4 & 7 & 2 & 13 & 5.4 \\
\hline Multiple case study (5 or more) & 1 & 26 & 4 & 31 & 12.9 \\
\hline Others & 4 & 6 & 8 & 18 & 7.5 \\
\hline Action research & & 6 & 6 & 12 & 5.0 \\
\hline Artificial evidence & 3 & & 2 & 5 & 2.1 \\
\hline Others & 1 & & & 1 & 0.4 \\
\hline Multiple & 7 & 2 & 10 & 19 & 7.9 \\
\hline Sample of companies and employees & 7 & & 1 & 8 & 5.0 \\
\hline Sample of companies and case study & & & 7 & 7 & 2.9 \\
\hline Sample of companies and experts & & & 1 & & 0.0 \\
\hline Sample of experts and case study & & 2 & & 2 & 0.8 \\
\hline Sample of experts and employees & & & 1 & 1 & 0.4 \\
\hline Total & 136 & 55 & 49 & 240 & 100 \\
\hline$\%$ Column & 56.7 & 22.9 & 20.4 & 100 & \\
\hline
\end{tabular}

Source: Author elaboration.

Table 5

Research design

\begin{tabular}{lrrrrrrrr}
\hline \multirow{2}{*}{ Category } & \multirow{2}{*}{ Total } & \% & \multicolumn{6}{c}{ Data gathering methods (counts) $\left(^{*}\right)$} \\
\cline { 5 - 10 } & & & A & B & C & D & E & F \\
\hline Not experimental & $\mathbf{2 3 5}$ & $\mathbf{9 8}$ & $\mathbf{1 6 0}$ & $\mathbf{9 3}$ & $\mathbf{3 1}$ & $\mathbf{2 2}$ & $\mathbf{2 0}$ & $\mathbf{4 3}$ \\
Cross-sectional & 169 & 70 & 145 & 44 & 12 & 15 & 17 & 20 \\
Longitudinal & 11 & 5 & 8 & 4 & & & 3 & 1 \\
Panel & 0 & 0 & & & & & & \\
Qualitative & 55 & 23 & 7 & 45 & 19 & 7 & & 22 \\
\hline Experimental & $\mathbf{5}$ & $\mathbf{2}$ & $\mathbf{3}$ & $\mathbf{2}$ & $\mathbf{0}$ & $\mathbf{1}$ & $\mathbf{0}$ & $\mathbf{2}$ \\
\hline \multicolumn{1}{c}{ Total } & $\mathbf{2 4 0}$ & $\mathbf{1 0 0}$ & $\mathbf{1 6 3}$ & $\mathbf{9 5}$ & $\mathbf{3 1}$ & $\mathbf{2 3}$ & $\mathbf{2 0}$ & $\mathbf{4 5}$ \\
\hline
\end{tabular}

Note: $\left(^{\star}\right)$ A (surveys), B (interviews), C (documentary analyses), D (panels or focus groups), E (existing databases), F (field observations/ measurements).

Source: Author elaboration.

In accordance with Meredith et al.s (1989) approach to the examination of research paradigms, OS investigation predominantly represents positivist/empiricist logic, with an approach to reality through people's perceptions of object reality (Table 7).

As observed in Figure 4, from the natural/artificial dimension, those studies with direct observation of object reality dou-
Table 6

Research typology

\begin{tabular}{|c|c|c|c|c|c|c|}
\hline \multirow[b]{2}{*}{ Typology 1} & \multicolumn{4}{|c|}{ Typology 2} & \multirow[b]{2}{*}{ Total } & \multirow{2}{*}{$\begin{array}{c}\% \\
\text { row }\end{array}$} \\
\hline & Exploratory & $\begin{array}{l}\text { Problem- } \\
\text { solving }\end{array}$ & $\begin{array}{l}\text { Testing- } \\
\text { out }\end{array}$ & $\begin{array}{l}\text { Theory- } \\
\text { building }\end{array}$ & & \\
\hline Historical & & & & & 0 & 0.0 \\
\hline Descriptive & 32 & 9 & 17 & 4 & 62 & 25.9 \\
\hline Correlational & 6 & 2 & 8 & 1 & 17 & 7.1 \\
\hline Explanatory & 1 & 3 & 87 & 1 & 92 & 38.3 \\
\hline Exploratory & 6 & 5 & 1 & 2 & 14 & 5.8 \\
\hline Qualitative & 25 & 10 & 5 & 15 & 55 & 22.9 \\
\hline Total & 70 & 29 & 118 & 23 & 240 & 100 \\
\hline$\%$ column & 29.1 & 12.1 & 49.2 & 9.6 & 100 & \\
\hline
\end{tabular}

Source: Author elaboration.

bled in the 2009-2017 period, as compared to previous years. Tendencies were not found in the rational/existential dimension, and it should be emphasized that the two studies from the axiomatic perspective corresponded to 2002 and 2016 (Choy et al. 2016; Lee et al. 2002). 
Table 7

OS research method paradigms

\begin{tabular}{|c|c|c|c|c|c|c|}
\hline & & & Natural/Artificia & & & \\
\hline & Dimensions & Direct observation & People's perceptions & Artificial reconstruction & Total & $\%$ Row \\
\hline & Axiomatic & & & 2 & 2 & 0.8 \\
\hline 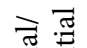 & Logical positivist/empiricist & 4 & 133 & 11 & 148 & 61.7 \\
\hline. & Interpretative & 22 & 46 & 5 & 73 & 30.4 \\
\hline 菊 & Mixed (positivist + interpretative) & 1 & 13 & & 14 & 5.8 \\
\hline & Mixed (axiomatic + interpretative) & 2 & & 1 & 3 & 1.3 \\
\hline & Total & 29 & 192 & 19 & 240 & 100 \\
\hline & $\%$ Column & 12.1 & 80.0 & 7.9 & 100 & \\
\hline
\end{tabular}

Source: Author elaboration.

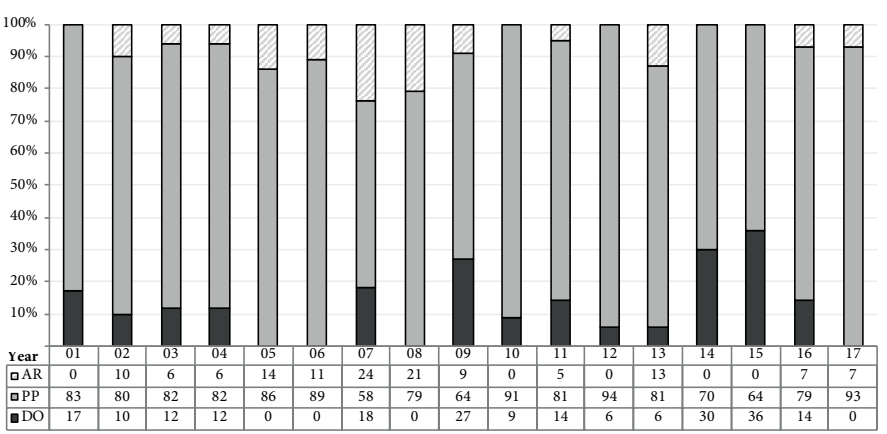

Figure 4

General results by paradigm (natural/artificial dimensions)

Source: Author elaboration.

Note: AR (artificial reconstruction of object reality), PP (people's perceptions of object reality), DO (direct observation of object reality).

The specific methods used by the encountered investigations, in order to obtain results, have been predominantly statistical. Figure 5 shows that the most used techniques included: differences in means, regression analysis, Structural Equation Modelling (SEM), cluster analysis and measures of association. Also, 12 articles were found to have designed or applied aggregate performance indicators. Diverse techniques and other mathematical theories have been little used in OS study (e.g., fuzzy logic, optimization, network analysis, etc.).

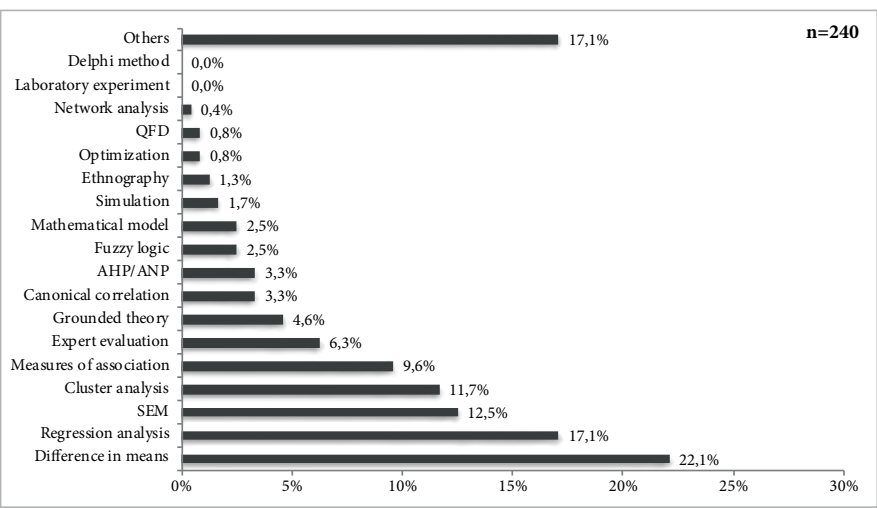

Figure 5

Methods used

Source: Author elaboration.

\section{DISCUSSION AND FUTURE RESEARCH AREAS}

OS investigation has been relatively prolific during the past few years. However, it is a field with great potential and multiple possibilities for future investigation. When considering the multiple, complex phenomena which intervene in a company's production/operations system, the possibilities for continued OS investigation appear to be unlimited. Below, a discussion will attempt to identify future areas, in the following order: topic perspectives and investigative paradigms for further research.

\subsection{Topic perspectives}

OS investigation continues to concentrate principally on content, and very little on the formulation process. This demonstrates the continuity of the tendency encountered by Dangayach and Deshmukh (2001). The OS formulation process is fertile ground for investigation, as there is no universal strategy which can be employed by all. Thus, each company must establish their own path to excellence (Schroeder and Flynn 2001). Miltenburg (2009, p. 6180) affirms this, stating that: "Many models are possible and there is no particular model that is best for all companies". Further investigation into the OS formulation process is required, particularly regarding matters such as: a) design and testing of models/methodologies/procedures for strategy formulation and implementation, b) the study of patterns in decision-making (top-down, bottom-up, and mixed), c) the evaluation and comprehension of different variables which affect the formulation process, such as: external, cultural, political, financial, stakeholders, learning, and discussion-interaction mechanism factors, in addition to project management for improvement of operations systems, among other things.

Competitive priorities have been studied chiefly as operations system performance indicators. Very few investigations, however, have simultaneously evaluated the degree of importance which each represent for company strategy. It is necessary to separate the capacities that a company wishes to strengthen in the future (priorities) in accordance with their importance for strategy, and their current ability/strength/capability to compete in the market (Corbett and Claridge 2002; Nauhria et al. 2011; 
Szász and Demeter 2014). Such a distinction would allow for evaluation of the adjustment of those competitive priorities that the operations system should pursue (objectives), along with the company's current reality. This perspective, however, has received little attention in OS investigations.

A hearty debate was identified, regarding models of analysis for competitive priorities, between the trade-off and sand cone paradigms. Numerous authors have provided evidence in favor of both the former (e.g. Boyer and Lewis 2002; da Silveira 2005) and the latter (e.g. Avella et al. 2011; Narasimhan and Schoenherr 2013), respectively. Others have advocated reconciliation, as consideration of certain contingencies that make one or the other the better choice, depending upon the operating frontiers (e.g. Lapré and Scudder 2004; Liu et al. 2011; Nand et al. 2013). Singh et al. (2015) studied 1,438 manufacturing plants, and provided evidence for the argument that, in addition to the tradeoff and sand cone models, the "threshold", "average", "multiple", and "uncompetitive" models could be added to the literature. It seems that the debate may continue for some time, although it is unclear whether this debate is fertile ground for the object of a practical case study. In one case study, da Silveira and Slack (2001, p. 962) concluded that: "Trade-offs are not the problematic issue for practicing managers that they are for academics". From an academic point of view, this may be worthy of investigation.

In addition to the four classic competitive priorities (cost, quality, delivery, and flexibility), a further three emerging priorities were detected: innovativeness, service, and environmental protection. These have received significant attention in the literature, as new priorities have clear implications for the operations system. As such, their specific examination, in relation to OS, may be relevant. It is important to mention that concepts associated with product innovativeness have frequently been included as one of the dimensions of flexibility in studies, instead of being considered separately. The various publications geared toward innovation, that have been identified, led to the proposal that it should be treated as a new competitive priority, not as a flexibility dimension. There are two reasons that make the incorporation of service relevant: firstly, the need to improve understanding of operations strategy in companies from the service sector, and secondly, the possibility that value may be created in manufacturing businesses by adding services which better the functionality and sustainability of manufactured products. Thus, interest in the study of servitization has grown in the literature (Martín-Peña et al. 2017; Zhou et al. 2020). As such, production/operations systems are called to actively participate in service.

In the case of environmental protection, growing social and political pressures have made this variable both a threat and an opportunity for OS. The study of strategies for green manufacturing was addressed by (Li et al. 2010). They, by way of a case study, investigated the planning and implementation of a green manufacturing strategy from the product life cycle perspective. They then proposed a theoretical model for a five-layer structure, geared toward developing countries. The "green" topic in operations is one that has been promoted by Sarkis (2001) and Dangayach and Deshmukh (2001), but which has commanded little research in the OS context. As such, it is a field which re- quires increased future investigation, and which, additionally, may be approached from a variety of perspectives. For example, as green human resource management is a recent investigative tendency (Yu et al. 2020), the analysis of its effect on operations system competitive performance is a topic which has yet to be examined. Those factors which affect the successful implementation of green practices form part of a field which still offers investigative possibilities (Digalwar et al. 2017), as does the problem of sustainability measurement (Mura et al. 2018). Another perspective might include the investigation of ways to effectively balance the triple-bottom line, as current models, focused on sustainability, inadequately integrate company competitiveness, according to the contributions of Ocampo and Clark (2017).

One point to be highlighted in the OS sphere is called Industry 4.0, or digitalization, which brings with it important implications for competitive priorities in manufacturing and other areas of decision-making, beyond process technology (human resource management, quality management, production planning, and inventory management, etc.). Industry 4.0, also known as the fourth industrial revolution, refers to the development of smart factories, which are interconnected and managed from computational space. This creates cyber-physical systems, which use the internet and more advanced technologies to simultaneously seek efficiency, quality, flexibility, reliability, and speed of delivery, among other manufacturing advantages (Lee 2008; Xu 2012; Drath and Horch 2014; Lee et al. 2014, 2015; Monostori 2014; Li et al. 2017).

However, the results of the review showed that this topic has not received attention from the OS perspective and is a tendency which should be investigated with additional discussion, in order to support decision-making in manufacturing systems. Industry 4.0 is a great opportunity with which to contribute to the expansion of the frontiers of knowledge. Multiple relevant approaches may enrich the OS field. Moreover, ways in which to engage Industry 4.0, to impact sustainability, is a missing link. Furstenau et al. (2020) describes the existing relationship between Industry 4.0 and sustainability, but this premise has not been reviewed sufficiently to formulate sustainable OS.

Besides, the analysis of interactions/interdependencies and the joint implementation of lean manufacturing and Industry 4.0 (Lean 4.0) is undoubtedly an emerging and promising topic in the field. Lean Manufacturing (LM) is different from Operations Strategy (OS). Although LM can be considered a potential choice for OS formulation, as a component of OS, LM is a way to make strategic decisions in companies. Among TQM, six sigma or business process reengineering, Slack and Lewis (2011) identified LM as a "new approach" to operations management. Said authors stated that, "These approaches are not strategies in themselves (operations strategy specific to one organisation at one point in time), they are generic in nature, but they are strategic decisions (Slack and Lewis 2011, p. 111)”. In any case, developments in Lean 4.0 offer multiple specific possibilities by which to engage OS framework, as exemplified below.

Pagliosa et al. (2021) revealed the existence of positive interaction between lean manufacturing practices and Industry 4.0 technologies, to achieve a higher operational performance. In the context of Norwegian companies, a study found that, “... 
when used together, they have a complementary (or synergistic) effect that is greater than their individual effects combined (Buer et al. 2021, p. 1976)". Kamble et al. (2020) found interactions among Industry 4.0, LM practices, and sustainable organizational performance in Indian companies. In line with Sony (2018), these findings permit the conclusion that new integration models for Industry 4.0 and LM are required. Beyond that, however, models are needed to integrate both into an OS decision-making framework. In general, possibilities to research these phenomena in the OS field constitutes a literature gap.

Finally, other fields demand further investigation in the OS field (for instance, Business Process Modelling (BPM) and its links with smart manufacturing). Sott et al. (2021a, p. 1391) stated: "...the need to develop new languages or extensions capable of representing the dynamism, interoperability and multiple technologies of smart factories". In this way, other study stated that, "Most of the studies are aimed at developing new frameworks or integrating languages with other techniques for mapping and modelling organizational processes (Sott et al. 2021b, p. 545)". Notwithstanding, this approach has been not addressed in the OS research, to support decision making.

\subsection{Investigative paradigms for further research}

The results of the present study revealed that OS investigation has been performed principally through use of surveys and case studies, with an important concentration on non-experimental designs, in which transversal data predominate, and longitudinal data are present on a lesser scale. This puts at least two challenges to investigators. On one hand, performing investigations with longitudinal data is pertinent, not just due to their scarcity, but also because they allow for the analysis of relationships between the analyzed variables, over time (de Menezes et al. 2010). This perspective is adequate for the strategy context, as the effects of decisions tend to be seen several years after the fact, not instantaneously.

On the other hand, experimental research has been effectively absent from OS investigation. Although it may be complex and difficult, in companies, it is possible to conduct experiments, quasi-experiments, and pre-experiments. For example, field experiments could be advanced, in order to obtain inputs to support OS formulation (e.g. Pullman et al. 2001), specific decision-making (e.g. Stading et al. 2001), testing of models for the analysis of relationships between variables, and scenario evaluation (e.g. Lee et al. 2002), or new models could be tested for OS formulation (Vivares et al. 2021). It would be quite a challenge to evaluate the effects of certain kinds of decision or strategy configurations, through non-destructive or controlled experiments. Also, the experimental application of models which tend to respond to "how" questions (how to perform a task, resolve problems, address contingencies) could be implemented, for example, in what ways can OS be formulated?

As an example, note that the "Balanced Scorecard" field was created by joint work between academics and practitioners, who were all trying to identify how to measure outcomes in companies of the future. Robert Kaplan and David Norton conducted a study with 12 companies, and some of these experimented with the application of a new theoretical development (Kaplan and Norton 1992). Of course, the result (balanced scorecard) was successful, and became famous in both scientific and practitioner communities. Thus, further research, oriented toward the solution of real problems in companies, is necessary. In fact, the literature review revealed that only $12.9 \%$ of investigations were of the problem-solving type, in which researchers would begin with a real-world problem, propose original solutions, and offer scientific evidence as support.

This kind of research may find epistemological support in an older research paradigm, known as action research. Westbrook (1995) promoted action research as "a new paradigm for research in production and operations management". Today, action research is considered to be completely legitimate in this field, and promotes collaboration between practitioners and investigators, in order to carry out rigorous projects which seek double contributions: both academic and practical (Coughlan and Coghlan 2002; Avella and Alfaro 2014). This paradigm could be useful to close the existing gap in the lack of experimental studies. It is very complex to perform pure experiments in organizations, but researchers could attempt quasi-experimental or pre-experimental research. One investigation, entitled action research as experimentation, concluded that:

Still, the metaphor of the laboratory is applicable because it enables for an understanding of how what Ian Hacking calls interventions in the "hard sciences" share certain characteristics with the action research activities. When action researchers intervene within organizations, the activities are always experimental in nature, i.e., they can never be fully predicted or anticipated, but are initial steps in an emergent process of organizational change (Styhre and Sundgren 2005, p. 53).

Thus, researchers study the OS phenomenon, their laboratories are companies, and they must innovate in their research. Fendt and Kaminska-Labbé (2011, p. 217) argue that, "Management innovation is happening everywhere and at a breathtaking pace. Everywhere that is, except in academia". These authors propose responses to this problem from the action research paradigm. However, action research has been marginalized in OS, as confirmed by this study's literature review. Promoting additional effort for this type of investigation would contribute to the improvement of the academia-business relationship, as well as stimulate knowledge transfer, which has been identified by various authors as a weakness (O'Sullivan et al. 2011; Rynes et al. 2001, Rynes et al. 2007; Shapiro et al. 2007).

From the point of view of research-support techniques, fuzzy logic, optimization, simulation, network analysis, and expert evaluation, among other things, emerge as adequate alternatives for the discussion of other investigative approaches. These techniques complement the use of statistical methods, with which the majority of OS investigation has been performed and permit a more complete understanding of the complex phenomena to be investigated in OS. It must be clarified that enrichment, and the use of other pertinent, legitimate paradigms, is being promoted. Dominant paradigm replacement is not.

The obtained results support a revealing finding: it may be said that OS has contributed to changing the dominant paradigm in the field from a production and operations management direction. Skinner (2007, p. 329) indicated that: 
In the late 1950s, while academics were still teaching time and motion study and being titillated by simulation, linear programming and algorithms, industry was awash with problems-quality and productivity, labor morale, the growing loss of markets to foreign competitors, equipment and process technology puzzles, to name only a few... So since no one was asking why things were going wrong, there was no way for managers to know what to do about it... I became a quiet rebel and slunk underground to try to figure out what was really going.

This assessment has been corroborated by Meredith et al. (1989), who observed that Operations Management (OM) investigation was concentrated on the "axiomatic" category of the rational/existential dimensions, and the "artificial construction of reality" in the natural/artificial dimensions (see Figure 6). The dominant type of investigation in the late 1950s, as mentioned by Skinner (2007), was located in just that quadrant, and he believed that a change would be suitable. His seminal contributions strengthened the understanding of manufacturing as a competitive weapon (Skinner 1969). In this review, it was found that, during the 2001-2017 period, OS moved toward the "People's perceptions of object reality" category, in the natural/artificial dimensions, and to the "Logical positivist/empiricist" category in the rational/existential dimensions. This is consistent with the findings of Craighead and Meredith (2008), who analyzed a sample of OM articles from 1995 and 2003 (separately), which reflected gradual movements in the aforementioned direction. It could be said, then, that the emergence of OS contributed to a change in the OM paradigm.

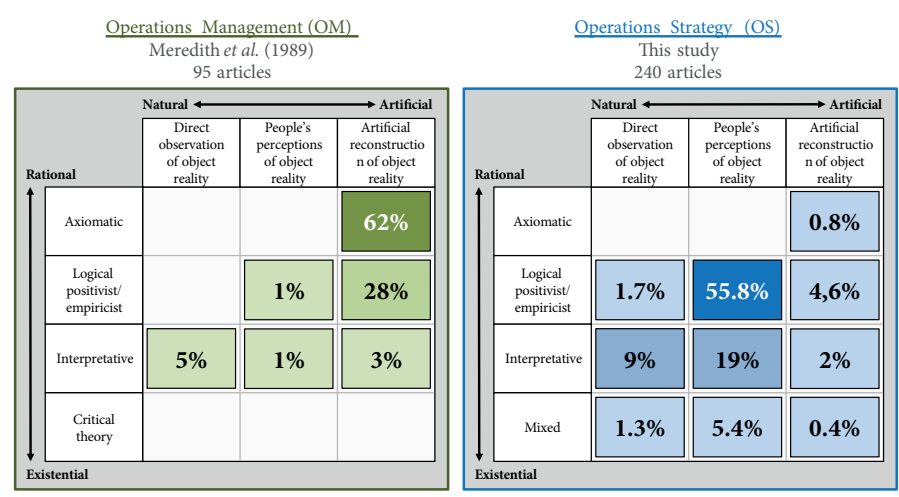

Figure 6

Comparison of results from Meredith et al. (1989) and the present study

Source: Author elaboration based on Meredith et al. (1989) and this study.

In the opinion of the authors of the present investigation, movement in the natural/artificial dimensions should continue toward investigations based on direct observation, balancing these with studies based on the people's perceptions of those close to a given reality. Additionally, real field experiments and projects within the action research paradigm are classified, within the axis of the direct observation of reality. These focuses have scarcely been addressed in the state of the art, despite their significant theoretical and practical importance. From this perspective, it is important to maintain a positivist/empiricist approach, or even a mixed approach, with an interpretative focus. Additionally, keeping the Industry 4.0 boom in mind, the performance of mixed investigations, based on data from direct observation and processed via artificial reconstruction of reality, in order to support decision-making, would allow for novel investigations to be performed and the expansion of the cutting-edge knowledge. Advancement, in this sense, would facilitate research relevance improvement and make both academic and practical contributions. Findings suggest the need to use alternative research paradigms, not the replacement of the current dominant paradigm. This is in line with the origin of the field: helping companies to learn how to resolve OS problems, and positioning manufacturing as a competitive weapon, as Wickham Skinner indicated.

There are many specific topics which may be addressed within this line of investigation, and they are of interest to practitioners as well as academics in general management. For example, considering that strategies are implemented via employee behavior, the development of models to transform objectives into specific organizational behaviors remains a fruitful line of investigation (Gagné 2018), as does approaching the strategic renewal processes that companies require to face today's dynamic environments (Schmitt et al. 2018). These topics require the development of dynamic capacities, a field with a number of open problems, including their measurement (Laaksonen and Peltoniemi 2018). Thus, future investigation should create knowledge which helps operations managers to identify, create, and measure the dynamic capacities for which they are responsible.

\section{CONCLUSIONS}

This investigation sought to identify principal tendencies and future research challenges, by way of a systematic literature review. It was found that investigation has centered on OS content. From the investigative point of view, testing-out studies predominate, and the majority of contributions are non-experimental, with transversal data. Although it may be complex and difficult, in companies, it is possible to conduct experiments, quasi-experiments, or pre-experiments in order to enrich OS research.

The dominant research paradigm is located at the intersection between the "people's perceptions of object reality" (natural/artificial dimensions), and "Logical positivist/empiricist" (rational/existential dimensions) categories, which represents a paradigm change, with respect to observations from the 70s and $80 \mathrm{~s}$ in the operations management field. It is concluded that a movement is occurring in the natural/artificial dimensions, toward investigations based on direct observation, as is balancing them with those based on peoples' perceptions, and maintaining a positivist/empiricist approach, or even one mixed with an interpretative approach. Furthermore, mixed investigations obtain data from direct observation, and are processed via the artificial reconstruction of reality to support decision-making.

Advancement, in this sense, would facilitate an improvement in research relevance and make both academic and practical contributions. Findings suggest the reinforcement of presence of alternative research paradigms, not the replacement of the current dominant paradigm. This in line with the origin of the field: helping companies to learn how to resolve OS problems, and positioning manufacturing as a competitive weapon. The results and discussion presented above allow emphasis to be placed on the following eight challenges for future research: 
- There is a need for studies centered on the direct observation of reality, which promote transference between investigators and practitioners, and which facilitate the solution of real problems for companies. From this perspective, the action research approach would be appropriate.

- Mixed investigations, which obtain data from direct observation, and which process via an artificial reconstruction of reality to support decision-making, would allow for the performance of novel investigations to move the frontiers of knowledge.

- Studies with longitudinal or panel data, and contributions with experimental designs would be challenging, and would enrich the state of the art.

- Investigations which develop new theories within the theory-building perspective, because the majority of empirical studies seek to prove or refute theories.

- Increased analysis in the OS formulation process, especially on topics such as the design and application of models/methodologies/procedures for formulation and implementation, pattern analysis in decision-making, and the diverse variables to be involved in the process.

- Innovativeness, service, and environmental protection have emerged as new competitive priorities, which require attention in the strategic orientation of operations systems. Advancement in these arenas constitutes a research opportunity. For example, additional research, oriented toward the comprehension of ways to effectively involve green manufacturing strategies and the sustainability concept in OS could improve environmental protection performance.

-With respect to management approaches for competitive priorities, the debate between the trade-off and sand cone paradigms remains both open and relevant.

- Involvement of the Industry 4.0 tendency to investigate decision-making in future manufacturing/operations systems. Is pertinent to study the effects of Industry 4.0 on competitive priorities and in strategic decision areas, as well as its implications in management practices (lean management, JIT, TPM, among others).

\section{SUPPLEMENTARY FILE}

A supplementary file with the 280 analyzed articles, information, and classification of these can be accessed at this URL: http://www.ehu.eus/cuadernosdegestion/documentos/Supplementary-File-21A1543.pdf

\section{ACKNOWLEDGMENT}

The authors wish to thank Universidad Nacional Abierta y a Distancia (project ECBTIPIE122021), Universidad de Oviedo, and Universidad Nacional de Colombia. Also, we thank to Minciencias for the first author's scholarship (announcement 567-12).

\section{REFERENCES}

AlDurgham, M.M. and Barghash M.A., 2008. A generalised framework for simulation-based decision support for manufacturing. Production Planning \& Control, 19(5), 518-534. DOI: 10.1080/09537280802187626
Arana-Solares I.A., Ortega-Jiménez C.H., Alfalla-Luque R. and Pérez-Díez de los Ríos J.L., 2019. Contextual factors intervening in the manufacturing strategy and technology management-performance relationship. International Journal of Production Economics, 207, 8195. DOI: $10.1016 /$ j.ijpe.2018.11.003

Avella L. and Alfaro J.A., 2014. Spanish University Business Chairs used to increase the deployment of Action Research in Operations Management: A case study and analysis. Action Research, 12(2), 194-208. DOI: $10.1177 / 1476750314528010$

Avella L., Vazquez-Bustelo D. and Fernandez, E., 2011. Cumulative manufacturing capabilities: an extended model and new empirical evidence. International Journal of Production Research, 49(3), 707-729. DOI: $10.1080 / 00207540903460224$

Bartels, E.M., 2013. How to perform a systematic search. Best Practice \& Research Clinical Rheumatology, 27(2), 295-306. DOI: 10.1016/j. berh.2013.02.001

Boyer K.K. and Lewis M.W., 2002. Competitive priorities: Investigating the need for trade-offs in operations strategy. Production and Operations Management, 11(1), 9-20.

Boyer K.K., Swink M. and Rosenzweig E.D., 2005. Operations strategy research in the POMS journal. Production and Operations Management, 14(4), 442-449.

Buer, S.V., Semini, M., Strandhagen, J.O. and Sgarbossa, F. 2021. The complementary effect of lean manufacturing and digitalisation on operational performance. International Journal of Production Research, 59(7), 1976-1992. DOI: 10.1080/00207543.2020.1790684

Kamble, S., Gunasekaran, A. and Dhone, N.C., 2020. Industry 4.0 and lean manufacturing practices for sustainable organisational performance in Indian manufacturing companies. International Journal of Production Research, 58(5), 1319-1337. DOI: 10.1080/00207543.2019.1630772

Chatha K.A. and Butt I., 2015. Themes of study in manufacturing strategy literature. International Journal of Operations \& Production Management, 35(4), 604-698. DOI: 10.1108/IJOPM-07-2013-0328

Chatha K.A., Butt, I. and Tariq A., 2015. Research methodologies and publication trends in manufacturing strategy: A content analysis based literature review. International Journal of Operations \& Production Management, 35(4), 487-546. DOI: 10.1108/IJOPM-07-2012-0285

Choy K.L., Ho G.T.S., Lee C.K.H., Lam H.Y., Cheng S.W.Y., Siu P.K.Y., Pang G.K.H., Tang V., Lee J.C.H. and Tsang Y.P., 2016. A recursive operations strategy model for managing sustainable chemical product development and production. International Journal of Production Economics, 181, 262-272. DOI: 10.1016/j.ijpe.2016.07.011

Corbett, L.M. and Claridge, G.S., 2002. Key manufacturing capability elements and business performance. International Journal of Production Research, 40(1), 109-131. DOI: 10.1080/00207540110073091

Corbetta, P., 2003. Social research: Theory, methods and techniques. Sage.

Coughlan, P. and Coghlan, D., 2002. Action research for operations management. International Journal of Operations \& Production Management, 22(2), 220-240. DOI: 10.1108/01443570210417515

Craighead, C.W. and Meredith, J., 2008. Operations management research: evolution and alternative future paths. International Journal of Operations \& Production Management, 28(8), 710-726. DOI: $10.1108 / 01443570810888625$

da Silveira, G.J.C., 2005. Improving trade-offs in manufacturing: Method and illustration. International Journal of Production Economics, 95(1), 27-38. DOI: 10.1016/j.ijpe.2003.10.023

da Silveira, G.J.C. and Sousa, R.S., 2010. Paradigms of choice in manufacturing strategy. Exploring performance relationships of fit, best practices, and capability-based approaches. International Journal of Operations \& Production Management, 30(12), 1219-1245. DOI: 10.1108/01443571011094244 
Da Silveira, G. and Slack, N., 2001. Exploring the trade-off concept. International Journal of Operations \& Production Management, 21(7), 949-964.

Dangayach, G.S. and Deshmukh, S.G., 2001. Manufacturing strategy: Literature review and some issues. International Journal of Operations \& Production Management, 21(7), 884-932. DOI: 10.1108/01443570110393414

de Menezes L.M., Wood S. and Gelade G., 2010. The integration of human resource and operation management practices and its link with performance: A longitudinal latent class study. Journal of Operations Management, 28(6), 455-471. DOI: 10.1016/j.jom.2010.01.002

Digalwar A.K., Mundra N., Tagalpallewar A.R. and Sunnapwar V.K., 2017. Road map for the implementation of green manufacturing practices in Indian manufacturing industries: An ISM approach. Benchmarking: An International Journal, 24(5), 1386-1399. DOI: 10.1108/BIJ-08-2015-0084

Drath, R. and Horch, A., 2014. Industrie 4.0: Hit or hype? IEEE Industrial Electronics Magazine, 8(2), 56-58. DOI: 10.1109/MIE.2014.2312079

Drohomeretski E., Gouvea da Costa S.E., Pinheiro de Lima E. and Garbuio P.A.D.R., 2014. Lean, six sigma and lean six sigma: An analysis based on operations strategy. International Journal of Production Research, 52(3), 804-824.

Durán, D., Robledo, S., Gomez, E., Arboleda, J.W. and Tarazona, N.A., 2021. Scientometric Overview of Coffee By-Products and Their Applications. Molecules, 26(24), 7605. DOI: 10.3390/molecules 26247605

Eisenhardt, K.M. and Graebner, M.E., 2007. Theory building from cases: Opportunities and challenges. Academy of Management Journalnal, 50(1), 25-32.

Fendt, J. and Kaminska-Labbé, R., 2011. Relevance and creativity through design-driven action research: Introducing pragmatic adequacy. European Management Journal, 29(3), 217-233. DOI: 10.1016/j. emj.2010.10.004

Ferdows, K. and De Meyer, A., 1990. Lasting improvements in manufacturing performance: In search of a new theory. Journal of Operations Management, 9(2), 168-184. DOI: 10.1016/0272-6963(90)90094-T

Fisher, M.L., 2007. Bob Hayes: Forty years of leading operations management into uncharted waters. Production and Operations Management, 16(2), 159-168.

Furstenau, L.B., Sott, M.K., Kipper, L.M., MacHado, E.L., Lopez-Robles, J.R., Dohan, M.S., Cobo, M.J., Zahid, A., Abbasi, Q.H. and Imran, M.A., 2020. Link between Sustainability and Industry 4.0: Trends, Challenges and New Perspectives. IEEE Access, 8, 140079-140096. DOI: 10.1109/ACCESS.2020.3012812

Gagné, M., 2018. From strategy to action: Transforming organizational goals into organizational behavior. International Journal of Management Reviews, 20, S83-S104. DOI: 10.1111/ijmr.12159

Granillo, R. and González, I.J., 2021. Selección y evaluación de proveedores de logística externa en la cadena de suministro: una revisión sistemática. Cuadernos de Gestión, 21(2), 7-18. DOI: 10.5295/ cdg.191141rg

Hayes, R.H and Wheelwright, S.C., 1984. Restoring our competitive edge: competing through manufacturing. Wiley.

Hayes, R.H. and Schmenner, R.W., 1978. How should you organize manufacturing? Harvard Business Review, 56(1), 105-118.

Hill, T., 2000. Manufacturing strategy: Text and cases. McGraw-Hill.

Kaplan, R.S. and Norton, D.P., 1992. The Balanced Scorecard Measures That Drive Performance. Harvard Business Review, January-February, 71-79.

Kim Y.H., Sting F.J. and Loch, C.H., 2014. Top-down, bottom-up, or both? Toward an integrative perspective on operations strategy formation. Journal of Operations Management, 32(7-8), 462-474. DOI: 10.1016/j.jom.2014.09.005

Kitchenham, B., 2004. Procedures for performing systematic reviews (Issue TR/SE-0401). DOI: 10.1.1.122.3308
Kulkarni S., Verma P. and Mukundan R., 2019. Assessing manufacturing strategy definitions utilising text-mining. International Journal of Production Research, 57(14), 4519-4546. DOI: 10.1080/00207543.2018.1512764

Laaksonen, O. and Peltoniemi, M., 2018. The essence of dynamic capabilities and their measurement. International Journal of Management Reviews, 20(2), 184-205. DOI: 10.1111/ijmr.12122

Lapré, M.A. and Scudder, G.D., 2004. Performance improvement paths in the U.S. airline industry: Linking trade-offs to asset frontiers. Production and Operations Management, 13(2), 123-134.

Lee, E.A., 2008. Cyber physical systems: Design challenges. 11th IEEE International Symposium on Object Oriented Real-Time Distributed Computing, 363-369. DOI: 10.1109/ISORC.2008.25

Lee J., Bagheri B. and Kao H.A., 2015. A Cyber-Physical Systems architecture for Industry 4.0-based manufacturing systems. Manufacturing Letters, 3, 18-23. DOI: 10.1016/j.mfglet.2014.12.001

Lee J., Kao H.A. and Yang, S., 2014. Service innovation and smart analytics for Industry 4.0 and big data environment. Procedia CIRP, 16, 3-8. DOI: 10.1016/j.procir.2014.02.001

Lee K., Jeong H., Park C. and Park J., 2002. Development of a decision-support system for the formulation of manufacturing strategy. International Journal of Production Research, 40(15), 3913-3930. DOI: $10.1080 / 00207540210161678$

Leong G.K., Snyder D.L. and Ward P.T., 1990. Research in the process and content of manufacturing strategy. Omega, 18(2), 109-122. DOI: 10.1016/0305-0483(90)90058-H

Li C., Liu F. and Wang Q., 2010. Planning and implementing the green manufacturing strategy: evidences from western China. Journal of Science and Technology Policy in China, 1(2), 148-162. DOI: 10.1108/17585521011059884

Li S., Madhok A., Plaschka G. and Verma R., 2006. Supplier-Switching Inertia and Competitive Asymmetry: A Demand-Side Perspective. Decision Sciences, 37(4), 547-576. DOI: 10.1111/j.15405414.2006.00138.x

Li X., Li D., Wan J., Vasilakos A.V., Lai C.F. and Wang S., 2017. A review of industrial wireless networks in the context of Industry 4.0. Wireless Networks, 23(1), 23-41. DOI: 10.1007/s11276-015-1133-7

Liu N., Roth A.V. and Rabinovich E., 2011. Antecedents and consequences of combinative competitive capabilities in manufacturing. International Journal of Operations \& Production Management, 31(12), 1250-1286. DOI: 10.1108/01443571111187448

Martín-Peña M.L., Pinillos M.J. and Reyes L.E., 2017. The intellectual basis of servitization: A bibliometric analysis. Journal of Engineering and Technology Management, 43(1), 83-97. DOI: 10.1016/j.jengtecman.2017.01.005

Meredith J. R., Raturi A., Amoako-Gyampah K. and Kaplan B., 1989. Alternative research paradigms in operations. Journal of Operations Management, 8(4), 297-326. DOI: 10.1016/02726963(89)90033-8

Miltenburg, J., 2008. Setting manufacturing strategy for a factory-within-a-factory. International Journal of Production Economics, 113(1), 307-323. DOI: 10.1016/j.ijpe.2007.09.001

Miltenburg, J., 2009. Setting manufacturing strategy for a company's international manufacturing network. International Journal of Production Research, 47(22), 6179-6203. DOI: 10.1080/00207540802126629

Monostori, L., 2014. Cyber-physical production systems: Roots, expectations and R\&D challenges. Procedia CIRP, 17, 9-13. DOI: 10.1016/j.procir.2014.03.115

Mura M., Longo M., Micheli P. and Bolzani D., 2018. The evolution of sustainability measurement research. International Journal of Management Reviews, 20(3), 661-695. DOI: 10.1111/ijmr.12179

Nand A.A., Singh P. and Power D., 2013. Testing an integrated model of operations capabilities: An empirical study of Australian airli- 
nes. International Journal of Operations \& Production Management, 33(7), 887-911. DOI: 10.1108/IJOPM-12-2011-0484

Narasimhan, R. and Schoenherr, T., 2013. Revisiting the progression of competitive capabilities: Results from a repeated cross-sectional investigation. International Journal of Production Research, 51(22), 6631-6650. DOI: 10.1080/00207543.2013.825739

Nauhria Y., Pandey S. and Kulkani M.S., 2011. Competitive priorities for indian car manufacturing industry (2011-2020) for global competitiveness. Global Journal of Flexible Systems Management, 12(3-4), 9-20.

O’Sullivan D., Rolstadås A. and Filos E., 2011. Global education in manufacturing strategy. Journal of Intelligent Manufacturing, 22(5), 663-674. DOI: 10.1007/s10845-009-0326-2

Ocampo, L. and Clark, E., 2017. Integrating sustainability and manufacturing strategy into a unifying framework. International Journal of Social Ecology and Sustainable Development, 8(1), 1-16. DOI: 10.4018/IJSESD.2017010101

Orviz, N., Cuervo, T. and Arce, S., 2021. Revisión de la investigación científica en ISO 9001 e ISO 14001: un análisis bibliométrico. Cuadernos de Gestión, 21(1), 29-45. DOI: 10.5295/CDG.191189NO

Pagliosa, M., Tortorella, G. and Ferreira, J.C.E., 2021. Industry 4.0 and Lean Manufacturing: A systematic literature review and future research directions. Journal of Manufacturing Technology Management, 32(3), 543-569. DOI: 10.1108/JMTM-12-2018-0446

Phillips, E.M. and Pugh, D.S., 2010. How to get a PhD: A handbook for students and their supervisors. McGraw-Hill, Open University Press.

Pullman M.E., Verma R. and Goodale J.C., 2001. Service design and operations strategy formulation in multicultural markets. Journal of Operations Management, 19(2), 239-254. DOI: 10.1016/S02726963(00)00059-0

Robledo S., Osorio G.A. \& López C., 2014. Networking en pequeña empresa: una revisión bibliográfica utilizando la teoria de grafos. Revista Vínculos, 11(2), 6-16.

Robledo, S., Aguirre, A.M., Hughes, M. and Eggers, F., 2021. "Hasta la vista, baby" - will machine learning terminate human literature reviews in entrepreneurship? Journal of Small Business Management, Pre-print. DOI: 10.1080/00472778.2021.1955125

Rynes S.L., Bartunek J.M. and Daft R.L., 2001. Across the great divide: Knowledge creation and transfer between practitioners and academics. Academy of Management Journal, 44(2), 340-355. DOI: $10.2307 / 3069460$

Rynes S.L., Giluk T.L. and Brown K.G., 2007. The very separate worlds of academic and practitioner periodicals in human resource management: Implications for evidence-based management. Academy of Management Journal, 50(5), 987-1008. DOI: 10.5465/AMJ.2007.27151939

Sarkis, J., 2001. Manufacturing's role in corporate environmental sustainability - Concerns for the new millennium. International Journal of Operations \& Production Management, 21(5/6), 666-686. DOI: 10.1108/01443570110390390

Schmenner, R.W., 1982. Multiplant manufacturing strategies among the fortune 500. Journal of Operations Management, 2(2), 77-86.

Schmitt A., Raisch S. and Volberda H.W., 2018. Strategic renewal: Past research, theoretical tensions and future challenges. International Journal of Management Reviews, 20(1), 81-98. DOI: 10.1111/ijmr.12117

Schroeder, R.G. and Flynn, B.B., 2001. High performance manufacturing. Global perspectives. John Wiley \& Sons.

Shapiro D.L., Kirkman B.L. and Courtney H.G., 2007. Perceived causes and solutions of the translation problem in management research. Academy of Management Journal, 50(2), 249-266. DOI: 10.5465/ AMJ.2007.24634433

Singh P.J., Wiengarten F., Nand A.A. and Betts T., 2015. Beyond the trade-off and cumulative capabilities models: alternative models of operations strategy. International Journal of Production Research, 53(13), 4001-4020. DOI: 10.1080/00207543.2014.983277
Skinner, W., 1966. Production under pressure. Harvard Business Review, 44(6), 139-146.

Skinner, W., 1969. Manufacturing-missing link in corporate strategy. Harvard Business Review, 47(3), 136-145.

Skinner, W., 1974. The focused factory. Harvard Business Review, 52(3), 113-121.

Skinner, W., 2007. Manufacturing strategy: The story of its evolution. Journal of Operations Management, 25(2), 328-335. DOI: 10.1016/j. jom.2006.10.008

Slack, N. and Lewis, M., 2011. Operations Strategy (Third Ed). Pearson Prentice Hall.

Sony, M., 2018. Industry 4.0 and lean management: a proposed integration model and research propositions. Production and Manufacturing Research, 6(1), 416-432. DOI: 10.1080/21693277.2018.1540949

Sott, M.K., Furstenau, L.B., Kipper, L.M., Reckziegel Rodrigues, Y.P., López-Robles, J.R., Giraldo, F.D. and Cobo, M.J., 2021a. Process modeling for smart factories: using science mapping to understand the strategic themes, main challenges and future trends. Business Process Management Journal, 27(5), 1391-1417. DOI: 10.1108/ BPMJ-05-2020-0181

Sott, M.K., Furstenau, L.B., Rodrigues, Y.P.R., Kipper, L.M., Tortorella, G.L., López-Robles, J.R. and Cobo, M.J., 2021b. Exploring the Evolution Structure of Process Modelling for Industry 4.0: a Science Mapping for Proposing Research Paths. International Conference on Industrial Engineering and Operations Management, 537-550.

Stading, G., Flores, B. and Olson, D., 2001. Understanding managerial preferences in selecting equipment. Journal of Operations Management, 19(1), 23-37. DOI: 10.1016/S0272-6963(00)00047-4

Styhre, A. and Sundgren, M., 2005. Action research as experimentation. Systemic Practice and Action Research, 18(1), 53-65. DOI: 10.1007/ s11213-005-2459-3

Szász, L. and Demeter, K., 2014. How do companies lose orders? A multi-country study of internal inconsistency in operations strategies. Operations Management Research, 7(3-4), 99-116. DOI: 10.1007/ s12063-014-0091-Z

Vivares, J.A. and Sarache, W. 2019. Manufacturing's strategic role and management practices: Evidence from colombian companies. In J.L. García Alcaraz, L. Rivera, R.G. González, G. Leal, and M.G. Chong (Eds.), Best Practices in Manufacturing Processes: Experiences from Latin America (pp. 325-345). Springer Nature Switzerland. DOI: 10.1007/978-3-319-99190-0_15

Vivares, J.A., Sarache, W. and Hurtado, J.E., 2021. A framework for the formulation of an operations strategy in manufacturing systems. In J.L. García Alcaraz, A. Realyvásquez, and E. Flores (Eds.), Trends in Industrial Engineering Applications to Manufacturing Process (pp. 435-462). Springer Nature Switzerland. DOI: 10.1007/978-3030-71579-3_18

Voss, C.A., 1995. Alternative paradigms for manufacturing strategy. International Journal of Operations \& Production Management, 15(4), 5-16. DOI: $10.1108 / 01443579510083587$

Wacker, J.G., 1998. A definition of theory research guidelines for different-theory building research methods in operations management. Journal of Operations Management, 16(4), 361-385. DOI: 10.1016/ S0272-6963(98)00019-9

Westbrook, R., 1995. Action research: a new paradigm for research in production and operations management. International Journal of Operations \& Production Management, 15(12), 6-20. DOI: 10.1108/01443579510104466

Wheelwright, S.C., 1978. Reflecting corporate strategy in manufacturing decisions. Business Horizons, 21(1), 57-66.

Wheelwright, S.C., 1984. Manufacturing strategy: defining the missing link. Strategic Management Journal, 5(1), 77-91. DOI: 10.1002/ smj.4250050106 
Xu, X., 2012. From cloud computing to cloud manufacturing. Robotics and Computer-Integrated Manufacturing, 28(1), 75-86. DOI 10.1016/j.rcim.2011.07.002

Yu W., Chavez R., Feng M., Wong C.Y. and Fynes B., 2020. Green human resource management and environmental cooperation: An ability-motivation-opportunity and contingency perspective. In- ternational Journal of Production Economics, 219, 224-235. DOI: 10.1016/j.ijpe.2019.06.013

Zhou D., Yan T., Zhao L. and Guo J., 2020. Performance implications of servitization: Does a Manufacturer's service supply network matter? International Journal of Production Economics, 219, 31-42. DOI: 10.1016/j.ijpe.2019.05.019 